\title{
Depilation increases while hairiness decreases the risk of drowning: A hitherto unappreciated survival role of setae in woolly bear caterpillars of the moth Lemyra imparilis (Lepidoptera: Noctuoidea: Erebidae)
}

\author{
V. BENNO MEYER-ROCHOW ${ }^{1,2}$ \\ ${ }^{1}$ Department of Genetics and Physiology, Oulu University, Oulu, FIN 90140, Finland; e-mail: victor.benno@oulu.fi \\ ${ }^{2}$ Research Institute of Luminous Organisms, Hachijo Island, 2872 Nakanogo, Hachijojima, Tokyo 100-1623, Japan; \\ e-mail: vbmeyrow@gmail.com
}

Key words. Lepidoptera, Erebidae, Lemyra imparilis, insect setae, cuticle, wettability, floating

\begin{abstract}
This note aims to put on record a hitherto unreported function of caterpillar setae supplementary to those already known. When woolly bear caterpillars of the moth Lemyra imparilis (Butler) have their body hairs removed and are dropped into a bucket of water from a height of $30 \mathrm{~cm}$, they sink immediately. Caterpillars, however, with an intact coat of hairs usually float. This hitherto unreported role of caterpillar setae as life-rafts should depend on a high contact angle $\theta_{\mathrm{e}}$, and thus on the position, density and dimensions of the hairs. An SEM examination of the surface structure of the setae revealed a system of fine grooves and small distally pointing barbs on the hair shaft, which can trap air to support the weight of the insect. Insect setae generally and body hairs of caterpillars in particular are known to possess many functions, but a role as life-rafts for caterpillars in danger of drowning can now be added to the list of possible uses of body hairs.
\end{abstract}

\section{INTRODUCTION}

Caterpillars covered in hairs are generally referred to as "woolly bears" (Conner, 2009). Scientifically the hairs are setae and thus a common feature of virtually all insects (Chapman 1998; Gullan \& Cranston, 2003). Consisting principally of a complex of three different cell types, a seta is a functional unit of firstly, the hair cell, often referred to as trichogen, producing the distal outgrowth (shaft), secondly, a basal enveloping tormogen cell producing the setal socket including the flexible ring around the base of the setal shaft, and thirdly, a sensory cell whose dendrite detects distortions of the base of the setal cuticle that it is in contact with (Dethier, 1963; Roeder, 1998). Additional cells like thecogen sheath cells and axon-wrapping glial cells can be present. The sensory cell's axon conveys the registered signal to the nervous system of the insect (e.g., Roeder, 1998; Insausti \& Lazzari 2000; Nation, 2008) where the decision to initiate or suppress a response to the signal occurs.

In addition to their sensory function, caterpillar setae may include non-sensory roles, e.g., to improve aero and fluid dynamics (Casas et al., 2010), aid in adhesion, protection and defence (Lederhouse, 1990; Castellanos et al., 2011; Sugiura \& Yamazaki, 2014).

Depending on their coloration, density and length they can, for instance, help a caterpillar blend with its environment (Skelhorn et al., 2010; Stevens \& Merilaita, 2011), or assist a caterpillar when it escapes by dropping and landing on the forest floor, rolled up into a furry ball and resting motionlessly amongst the veg- etation (Colson \& Witter, 1984). Yet the coat of long hairs can not only buffer the caterpillar's fall of sometimes several metres onto hard ground as it functions like a spring, it also makes the hairy caterpillar less palatable to birds, protects it against ant and other insects' attacks (Sugiura \& Yamazaki, 2014) and may even insulate it against the cold when the latter is not too severe and prolonged (Chapman \& Bolen, 2015). Protection against harmful UV-radiation could be another apparently not yet studied beneficial side effect of a dense coat of hair.

Most of all, however, a caterpillar's setae due to their sensitivity to touch as well as substrate and (in some setal types) air-borne vibrations (Meyer-Rochow, 1972; Scott \& Yack, 2012) convey mechanosensory information including intraspecific communication between individuals or early warning to the approach of enemies such as parasitoid wasps that wish to lay their eggs on or into a caterpillar's body (Markl \& Tautz, 1975; Tautz \& Mark1, 1978). Tactile setae in Brenthia caterpillars have been described as part of an elaborate defence strategy (Rota \& Wagner, 2008) and the long dorsal hairs in L. imparilis were shown to be an effective deterrent for predatory carabid beetles (Sugiura \& Yamazaki, 2014). The urticating properties of the hairs of woolly bear caterpillars, e.g., Orgyia leucotstigma and many others (Matheson, 1950; Blum, 1981; Wirtz, 1984) are well known and hairs to accommodate the venom have been described (Pesce \& Delgado, 1971; Lamdin et al., 2000).

Surprisingly, given the thorough treatment of caterpillar setae and their many diverse roles, one supplementary function appears 


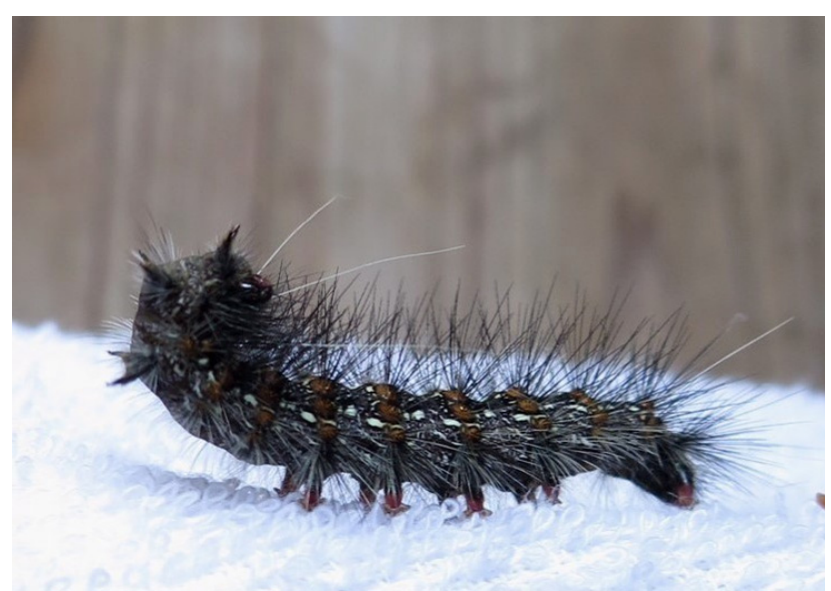

Fig. 1. Fifth instar woolly bear caterpillar of the moth Lemyra imparilis.

to have been overlooked. Having observed in the field and in the laboratory caterpillars of the moth Lemyra imparilis Butler, 1877 on the Japanese Izu Island of Hachijojima, I discovered a hitherto apparently undescribed additional role of the setae: they can prevent hairy caterpillars from drowning when they accidentally fall into water. These observations were then followed up with an examination by scanning electron microscopy of the setal surface fine structure and a discussion of the criteria that the hairs have to meet in order to be able to save a caterpillar's life.

\section{MATERIAL AND METHODS}

Only fifth instar woolly bear caterpillars (Fig. 1) of the erebid species Lemyra imparilis (Butler, 1877) (given as Spilosoma imparilis Butler in Ishiki et al., 1965), measuring around $28 \mathrm{~mm}$ in length, were collected from shrubs and trees at a location $\left(33^{\circ} 04^{\prime} \mathrm{N}\right.$; $\left.139^{\circ} 48^{\prime} \mathrm{E}\right)$ on the Izu island of "Hachijojima" (Japan). The insects were taken to the laboratory and kept in a refrigerator at $6^{\circ} \mathrm{C}$ for a few hours to render them less active and easier to handle when body hair depilation occurred. Depilation that removed approximately $80 \%$ of the hairs was carried out by hand with micro-scissors under a dissecting microscope. Five individual caterpillars with their coat of body hairs removed crawled around seemingly unperturbed. Serving as controls were caterpillars collected at the same time from the same site and treated in the same way as the depilated ones (i.e. kept in the fridge at around $6^{\circ} \mathrm{C}$ for approximately $24 \mathrm{~h}$ prior to testing them).

For the survival test one caterpillar at a time, alternating between depilated and controls, was dropped from a height of 30 $\mathrm{cm}$ into a bucket of cold tap water. This height was chosen as fifth instar caterpillars usually descend to lower branches not far above the ground. As a criterion and cut-off point survival for $1 \mathrm{~min}$ was mandatory. Within this time it could be assumed that a caterpillar would either make it out of the water by wriggling randomly around on the surface to accidentally reach something to crawl on or drown as preliminary observations had shown. Whether caterpillars sank or floated after one minute was then recorded.
As an additional control 5 more un-depilated caterpillars were dropped into the bucket together. Given the clear results (Table 1) it seemed unnecessary to sacrifice more animals. Moreover, because of the small numbers of animals involved and because all 5 depilated caterpillars (but just one of the 10 hairy ones) immediately sank to the bottom of the bucket after hitting the water, only Fisher's exact test was carried out.

For scanning electron microscopy (SEM) parts of a caterpillar's skin with setae present were either rinsed for $1 \mathrm{~min}$ in absolute acetone and then fixed according to a method recently described by Takaku et al. (2013) or the acetone treatment was skipped. The logic behind this was to see if the setae might be coated with a thin layer of lipid (Peters, 2003), which could be removed with acetone. Specimens were observed in a JEM7100F JEOL high-pressure scanning electron microscope at $1 \mathrm{kV}$.

\section{RESULTS AND DISCUSSION}

\section{Behaviour of depilated and hairy caterpillars when dropped into water}

All 5 caterpillars that had approximately $80 \%$ of their setae removed and were dropped one by one from a height of $30 \mathrm{~cm}$ into a bucket of freshwater sank instantly and following a few seconds of writhing and wriggling at the bottom of the bucket died by drowning in less than a minute. To revive them, by removing them from the water and covering them with powdered salt to withdraw the liquid from their tracheal system, was not tried.

Of the altogether ten caterpillars with an intact coat of setal hairs, all but one still floated on the surface of the water one minute (the target duration of the test) after being dropped into the bucket from the same height the hairless caterpillars had been dropped (Table 1). Why one caterpillar, despite its coat of hairs, sank is unclear and could have had something to do with the way it hit the water surface (perhaps head first versus lengthwise), its gut content or extraneous material between the setae. That issue, however, was considered less interesting (not worth following up) than the fact that 9 out of ten caterpillars, with one halfway submerged but still floating at the surface, survived not only for at least one minute in the water, but actually moved along the water surface for many more minutes until they reached the edge of the bucket, which they then duly ascended. If any of the floating caterpillars was pushed physically under water, it would sink to the bottom of the bucket and join the depilated individuals.

The simple experiment reported in this paper has shown that the caterpillar's setae, quite apart from some of the functions that hairs on caterpillars generally are suspected or known to posses (see Introduction), can help caterpillars survive when they fall into water. This can happen when strong winds dislodge the insect from the plant or by the insect's deliberate action of dropping in an attempt to evade a predator. With an annual precipitation of well over 3,000 mm, rains on Hachijojima can be extraordinarily heavy, but this author managed only once to see a single mature caterpillar washed into puddle. However, caterpillars often allowed themselves to drop when touched. Thus, a closer look at the hairs' locations, dimensions and surface fine structure seemed warranted. Slow motion camera takes of the way the caterpillar's

Table 1. Experimental evidence that hairy caterpillars of the moth Lemyra imparilis sink less quickly than depilated ones when dropped from a height of $30 \mathrm{~cm}$ onto water and a survival period criterion of $1 \mathrm{~min}$ is set. According to Fisher's Exact Test $p=0.002$, demonstrating that the differences are statistically significant.

\begin{tabular}{lccc}
\hline Condition & $\begin{array}{c}\text { Number of individuals dropped } \\
\text { from } 30 \mathrm{~cm} \text { into bucket of water }\end{array}$ & $\begin{array}{c}\text { Number of individuals } \\
\text { floating after 1 min }\end{array}$ & $\begin{array}{c}\text { Number of individuals } \\
\text { drowned after 1 min }\end{array}$ \\
\hline Depilated & 5 & 0 & 5 \\
Hairy & 10 & 9 & 1 \\
\hline
\end{tabular}




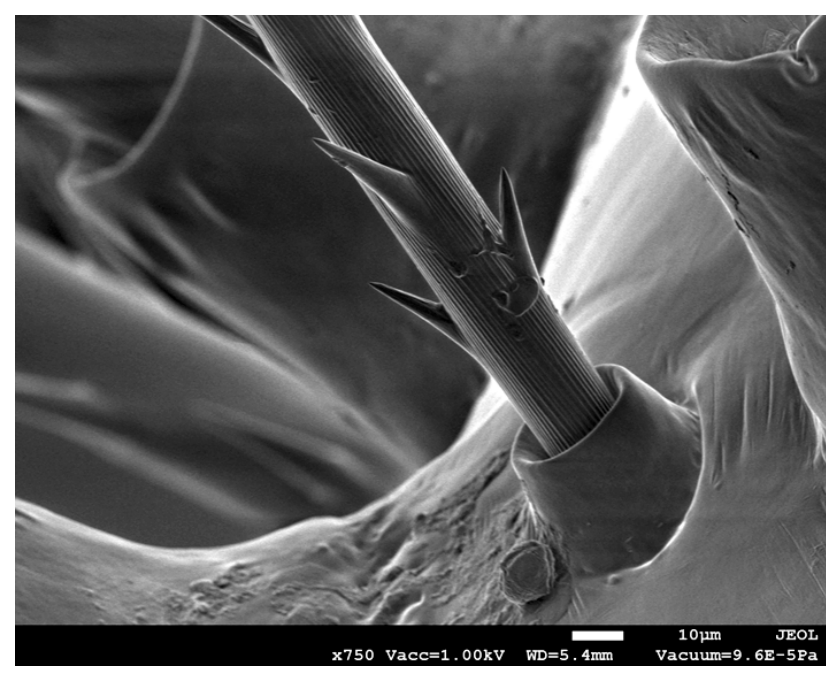

Fig. 2. Scanning electron micrograph of the basal region of a body hair, showing barbs on the hair's shaft and some fine ridges and grooves running along the length of the hair.

hairy body behaves aerodynamically during free fall and how it then contacts the water surface could also have been of significance (cf. free-falling ants: Yanoviak et al., 2005) but the equipment was not available.

\section{Setal structural characteristics}

The relative magnitudes of $\sigma$ (surface tension), $\gamma_{\mathrm{SL}}$ (solid-liquid energy) and $\gamma_{\mathrm{SG}}$ (solid-gas energy) allow one to calculate the contact angle $\theta_{\mathrm{e}}$, which is crucial for an understanding of the wettability of a solid substance in air on the surface of a liquid (Young, 1805, cited in Bush et al., 2008). The lower the value for $\theta_{e}$, the greater its potential wetting. Unsurprisingly, bees wax has a value of $\theta_{\mathrm{e}}$ as high as $97^{\circ}$, while hairless caterpillars of the moths Polia oleracea and Mamestra brassicae have values of just $18^{\circ}$ and therefore can be considered hydrophilic. However, had they possessed hairs, $\theta_{\mathrm{e}}$ could have been expected to be greater and wettability reduced (Pal, 1950). Unfortunately for hairy caterpillars no value of $\theta_{\mathrm{e}}$ is known, but for a single body hair of an adult moth a value of $97^{\circ}$ has been published by Pal (1950).

In 28-30 mm long last instar L. imparilis caterpillars, the longest hairs measure $15 \mathrm{~mm}$ and are inserted near the front end of the animal, pointing mainly forward and sideways (Fig. 1). Although black and white hairs, otherwise seemingly identical in structure, are present on all of the body's segments projecting radially away from the caterpillar's longitudinal axis in no preferred direction and subtending an arc of 180 degrees, four exceedingly long hairs measuring up to $15 \mathrm{~mm}$ in length and always white in colour were present in the front half of the body, extending far beyond the insect's anterior end. Longer than average white hairs were also present at the posterior end of the caterpillar, which suggests that these hairs, even more than any of the others, act principally as remote tactile sensors.

Pointing radially outward and away from the caterpillar's main body axis, the setae did not cover the caterpillar's integument randomly but sprouted from $0.3 \mathrm{~mm}$ high skin hillocks (shallow tubercles on the skin's surface) that were positioned in segmentally arranged arcs around the insect's body, separated from each other by approximately $1.5-2 \mathrm{~mm}$. Individual hillocks of a single arch were spaced approximately $1 \mathrm{~mm}$ apart. Corresponding to the caterpillar's segments, there were in total 11 such arcs with their respective setal hillocks, three on either side of the white dorsal midline that ran along the length of the caterpillar's body. Each of such hillocks carried an assemblage of 30-40 setae sat

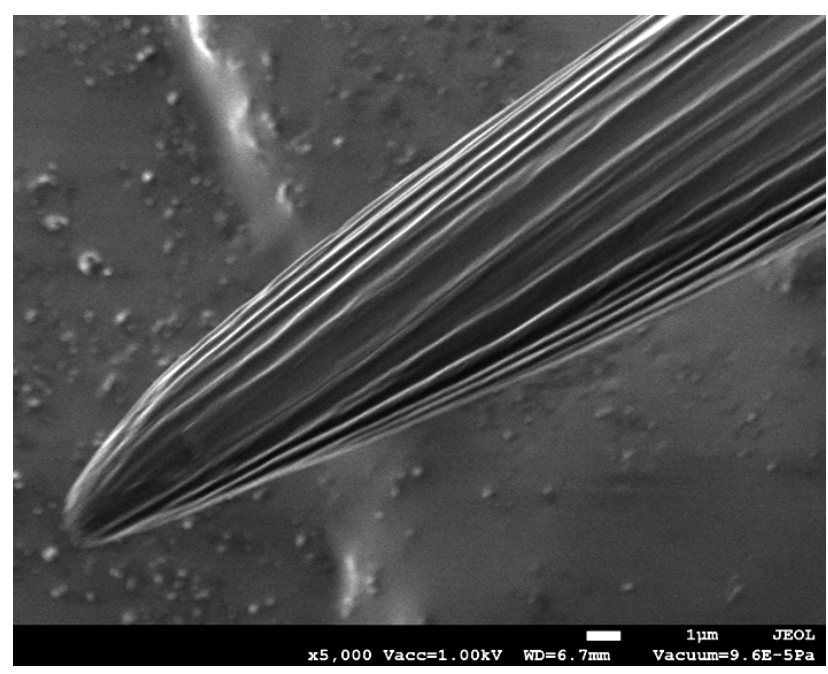

Fig. 3. Scanning electron micrograph showing nano-grooves and the tip of a hair.

at an angle and resembling miniature pin cushions with needles stuck in them.

Apart from the colour difference between the long white anterior and posterior setae and the shorter black or white body setae, no apparent structural differences between white and black hairs seemed to exist. Body setae, depending on their lengths, typically measured $30-80 \mu \mathrm{m}$ in diameter at their base and both black as well as white hairs possessed tiny barbs on their shaft pointing distally, i.e., away from the body and the base of the hair (Fig. 2). The angle between hair shaft and barb decreased from approx. 45 degrees near the hair's base to around 20 degrees and less towards the tip of the hair.

The distances between individual barbs, which seemed to have no preference with regard to the side of a hair's shaft, were smaller near the hair's base than at the tip of the hair with sometimes more than one barb present together with others at the same location. Measuring 20-30 $\mu \mathrm{m}$ in length and terminating in a sharp point, barbs closer to the hair's distal end rather than its base were much shorter. Very fine grooves of approx. $1 \mu \mathrm{m}$ near a hair's base and narrowing as well as fusing towards the hair's tip ran along the length of the hair (Fig. 3) Surfaces of this kind are frequently encountered in mechanoreceptive setae presumably to increase their strength without making them unnecessarily heavier. Since the grooves showed up best in micrographs of samples that had been treated with acetone prior to processing, it seems likely that a very thin layer of lipid covered the hair in the untreated specimens. The grooves would not only render these hairs firmer, but also increase the surface area and help trapping a thin layer of air.

\section{How can the caterpillar's body hairs save the insect from drowning?}

How these hairs and their barbs help a caterpillar survive when it has fallen into the water depends on several factors, related to the chemical and physical properties of the hairs as well as their total number and density. Assuming the hairs are not hydrophilic (which can be expected) and may even possess a thin coating of lipid (which is likely, see above), then simply due to their hydrophobic qualities they would assist the caterpillar to float on the water surface. According to Bush et al. (2008), the weight of an organism is "supported by a combination of buoyancy and curvature forces ... equal to the weight of fluid displaced by the meniscus". It follows from that and Fig. 6 in Bush et al. (2008) that many thinner hairs are better than a few thicker ones and an 
increase in the number of hairs in touch with the water surface increases the volume of fluid displaced and therefore the concomitant forced buoyancy.

If additionally the hairs were to possess nanogrooves (as they do in L. imparilis) to trap air in or between them, then the hairs' function as a life-saving float would be vastly improved. Incidentally, in all water-walking insects hairs appear to have nanogrooves and are tilted "to meet the water surface at an oblique angle" rather than piercing it (Bush et al., 2008). Were the hairs of $L$. imparilis caterpillars too long and stiff, the perilous caterpillar's aimless attempts to "crawl" and "wriggle" along the surface of the water to regain solid ground could be hampered. Firstly, with stiff and pointed setae penetrating the meniscus of the water the insect would become less buoyant and be in danger of sinking; secondly, if the setae do not penetrate the water, but because of their length lift the insect well above the water surface, then the insect might not be able to reach the water surface with its legs or body. It would depend entirely on where the wind and current might take it or it would need to bend its body in order to move forward, thereby risking to pierce the meniscus of the water on which it is floating. It follows that in order to fulfil their functions as life savers, the hairs must be thin and strong, but not too stiff; there should be an optimal density of them and distally a hair must end in a bendy slender tip.

If the hairs are too sparse, then air cannot successfully be trapped between them, buoyancy is reduced and an oxygen supply to the spiracles cannot be maintained, but if the coat of hairs is too dense, it might interfere with movements and moulting or represent other disadvantages during the caterpillar's larval life amongst vegetation or when it has fallen into the water. Since the barbs on individual hairs are always pointing distally and are not curved, their function cannot be to link neighbouring hairs together to create a more efficient air trap. More likely the way the barbs are oriented make it more difficult for parasitoid insects to enter between the setae and deposit eggs onto the caterpillar's body ( 23 out 80 L. imparilis caterpillars observed by Maruyama \& Kamioka, 1963 died from attacks by the tachinid fly Ctenophorocera townsendi and species of the ichneumonid genus Limnerium). Moreover barbs oriented in the opposite direction in all likelihood would lead to an accumulation of trapped and unwanted debris, increasing the chance of infections and problems during moulting.

In view of these considerations it should be interesting in a follow-up study to examine different instars and to determine their weights and degree of hairiness in relation to floating ability and fending off attacks by parasitoids. Setal morphology, length, width, and stiffness are also important under both scenarios, and to know which combinations of them dominate at different larval developmental stages could help to shed further light on the role of the caterpillar's hairiness.

\section{CONCLUSION}

Obviously setal structure and chemical composition as well as density, length and even colour of the setae have to be in tune with the performance of these hairs in the many roles they are meant to play. Saving caterpillars from drowning is not likely to be their main role and neither may be weakening a fall onto the ground or protection against the cold. Sensing the approach of a predator and rendering it more difficult for the latter to consume the caterpillar or to have a parasitoid deposit its eggs on it are likely to be more important tasks of the body setae. However, it is the combination of the hairiness' survival value under all these possible life-threatening situations (which includes the role as a life-raft) that ultimately has led to the evolution of the optimal setal characteristics and the arrangement and density of the setae on the caterpillar's body.

ACKNOWLEDGEMENTS. The author wishes to thank T. Hariyama for his hospitality and invitation to work in his laboratory at Hamamatsu Medical University and Y. Takaku and C. Nakane for expert processing of the material and the scanning electron microscopy. Mr. Kawabata of Kashitate Mihara Junior High School helped to identify the species $L$. imparilis.

\section{REFERENCES}

Buum M.S. 1981: Chemical Defences of Arthropods. Academic Press, New York, 562 pp.

Bush J.W.M., Hu D.L. \& Prakash M. 2008: The integument of water-walking arthropods: form and function. - Adv. Insect Physiol. 34: 118-192.

Casas J., Steinmann T. \& Krijnen G. 2010: Why do insects have such a high density of flow-sensing hairs? Insights from the hydrodynamics of biomimetic MEMS sensors. - J. R. Soc. Interface 7: 1487-1495.

Castellanos I., Barbosa P., Zuria I., Tammaru T. \& Christman M.C. 2011: Contact with caterpillar hairs triggers predatorspecific defensive responses. - Behav. Ecol. 22: 1020-1025.

CHAPMAn R.F. 1998: The Insects: Structure and Function. Cambridge University Press, Cambridge, $788 \mathrm{pp}$.

Chapman B.R. \& Bolen E.G. 2015: Ecology of North America. Wiley Blackwell, Chichester, 352 pp.

CONNeR WE. 2009: Tiger Moths and Woolly Bears. Oxford University Press, Oxford, 303 pp.

Coulson R.N. \& WitTer J.A. 1984: Forest Entomology, Ecology and Management. John Wiley \& Sons, New York, 669 pp.

DethiER V.G. 1963: The Physiology of Insect Senses. John Wiley \& Sons, New York, 266 pp.

Gullan P.J. \& Cranston P.S. 2003: The Insects. An Outline of Entomology. Blackwell, Oxford, 584 pp.

InSAUSTI T.C. \& LAZZARI C.R. 2000: The central projection of cephalic mechanosensory axons in the haematophagous bug Triatoma infestans. - Mem. Inst. Oswaldo Cruz (Rio de Janeiro) 95: 381-388.

Ishiki S., Yамамото Y. \& Hattori I. 1965: Colours of Japanese Moth Caterpillars Picture Book. Hoikusha, Osaka, Japan [in Japanese].

Lamdin J.M., Howell D.E., Kocan K.M., Murphey D.R., Arnold D.C., Fenton A.W. \& Odell G.V. 2000: The venomous hair structure, venom and life cycle of Lagoa crispata, a puss caterpillar of Oklahoma. - Toxicon 38: 1163-1189.

LEDERHOUSE R.C. 1990: Avoiding the hunt: primary defences of lepidopteran caterpillars. In Evans D.L. \& Schmidt J.O. (eds): Insect Defences: Adaptive Mechanisms and Strategies of Prey and Predators. State University of New York Press, Albany, pp. 175-190.

MARKL H. \& TAUTZ J. 1975: The sensitivity of hair receptors in caterpillars of Barathra brassicae L. (Lepidoptera, Noctuidae) to particle movement and sound field. - J. Comp. Physiol. 99: $79-87$.

Maruyama T. \& KamioKa S. 1963: Rearing experiment of Lemyra imparilis Butler (Lepidoptera: Arctiidae) on artificial diet. - J. Seric. Sci. Jap. 32: 268-270.

Matheson R. 1950: Medical Entomology. Comstock Publ., Ithaca, $629 \mathrm{pp}$.

MEYer-Rochow V.B. 1972: Verständigungsweisen bei koloniebildenden Blattwespen- und Käferlarven. - Z. Tierpsychol. 30: 451-455.

Nation J.L. 2008: Insect Physiology and Biochemistry. CRC Press, Taylor \& Francis, Baton Rouge, 560 pp. 
PAL R. 1950: The wetting of insect cuticle. - Bull. Entomol. Res. 41: 121-139.

Pesce H. \& Delgado A. 1971: Poisoning from adult moths and caterpillars. In Bücherl W., Buckley E.E. \& Deulofeu V. (eds) Venomous Animals and Their Venoms. Vol. 3. Academic Press, New York, pp. 119-156.

Peters W. 2003: Integument. In Dettner K. \& Peters W. (eds): Lehrbuch der Entomologie. Spektrum, Heidelberg, pp. 1-43.

Roeder K.D. 1998: Nerve Cells and Insect Behavior. Harvard University Press, Cambridge, 183 pp.

Rota J. \& Wagner D.L. 2008: Wormholes, sensory nets and hypertrophied tactile setae: the extraordinary defence strategies of Brenthia caterpillars. - Anim. Behav. 76: 1709-1713.

Sсотт J.L. \& YACK J.E. 2012: Vibrational territorial signals in caterpillars of the poplar lutestring Tethea or (Lepidoptera: Drepanidae). - Eur. J. Entomol. 109: 411-417.

SKelhorn J., Rowland H.M. \& Ruxton G.D. 2010: The evolution and ecology of masquerade: camouflage without crypsis. Biol. J. Linn. Soc. 99: 1-8.
Stevens M. \& Merilaita S. 2011: Animal camouflage. In Stevens M. \& Merilaita S. (eds): Animal Camouflage: Mechanisms and Function. Cambridge University Press, Cambridge, pp. 1-17.

Sugiura S. \& YAMAZAKI K. 2014: Caterpillar hair as a physical barrier to invertebrate predators. - Behav. Ecol. 25: 975-983.

Takaku Y., Suzuki H., Ohta I., Ishi D., Muranaka Y., Shimomura M. \& HARIYAMA T. 2013: A thin polymer membrane nano-suit, enhancing survival across the continuum between air and high vacuum. - Proc. Natn. Acad. Sci. 110: 7631-7635.

TautZ J. \& MarkL H. 1978: Caterpillars detect flying wasps by hairs sensitive to airborne vibration. - Behav. Ecol. Sociobiol. 4: 101-110.

WIRTZ R.A. 1984: Allergic and toxic reactions to non-stinging arthropods. - Annu. Rev. Entomol. 29: 47-69.

YanoviaK S.P., Dudley R. \& Kaspari M. 2005: Directed aerial descent in canopy ants. - Nature 443: 6624-6626.

Young T. 1805: An essay of the cohesion of fluids. - Phil. Trans. R. Soc. Lond. (A) 95: 65-87.

Received October 26, 2015; revised and accepted January 4, 2015 Published online January 28, 2016 